\title{
Epithelioid hemangioendothelioma: 15 years at the National Cancer Institute. Literature review
}

\author{
Hemangioendotelioma epitelioide: 15 anos no Instituto Nacional de Câncer. \\ Revisão da literatura
}

Ana Karla Araújo Cavalcanti de Albuquerque'; Sérgio de Oliveira Romano² Ana Lucia Amaral Eisenberg³

\begin{abstract}
Introduction: Hemangioendotheliomas are locally aggressive vascular tumors with intermediate malignity and metastasis risk. The epithelioid variant, the most aggressive one, equally affects men and women at any age and it is rare in children. It occurs as a solitary tumor, which is usually painful, affecting superficial or deep soft tissues. Furthermore, it is less frequent in the liver, lung, bones, skin, lymph nodes and central nervous system. Microscopically, they present epithelioid cells with intracytoplasmic vacuoles, low mitotic activity and little or no necrosis. Additionally, its vascular nature is confirmed by immunohistochemical studies (CD31, CD34 and factor VIII). Objective, material and methods: Through search in the archives of the Pathology Division of the National Cancer Institute (Instituto Nacional de Câncer [INCA]) from 1996 to 2011, 13 cases of epithelioid hemangioendothelioma (HEE) were identified and analyzed. Results and discussion: seven cases occurred in male patients and six in female patients, mean age 42 years, ranging from 7-66. The most common locations were: soft tissue (three patients; $23 \%$ ); head and neck, mediastinum, bone and lung (two patients each; 15\%); liver and lymph nodes (one patient each; $8 \%$ ). There was clinical follow-up of nine patients: five were alive and disease-free (one to six years after diagnosis); three out of four patients with aggressive disease progressed to death (one month to five years after diagnosis); one relapsed two years after diagnosis and is alive with disease. Conclusion: This series of 13 cases of HEE, whose diagnoses were based on morphological and/or immunohistochemical analyses, demonstrates the different patterns of clinical presentation and biologic behavior of this disease.
\end{abstract}

Key words: borderline vascular tumors; vascular tumors of intermediate malignancy; epithelioid hemangioendothelioma.

\section{INTRODUCTION}

Hemangioendotheliomas are vascular tumors with intermediate biologic behavior between hemangioma and angiosarcoma, commonly associated with a high rate of local relapse and low risk of distant metastasis in comparison with malignant tumors ${ }^{(4,12,28,37)}$. Hemangioendotheliomas are classified into the following histological subtypes: kaposiform, Dabska-retiform (or hobnail), compound or complex, low grade polymorphic and epithelioid ${ }^{(6,28,31)}$. This last variant is described as the most aggressive one and with acknowledged metastatic potential. It equally affects men and women at any age and it is rare in children ${ }^{(6,10,13,16,26)}$.

The aggressiveness of epithelioid hemangioendotheliomas (HEE) is exemplified by the high rates of metastasis (20\% to 30\%) and mortality (10\% to $20 \%)$, mainly when it affects soft tissue and viscera $^{(6,12,22,25,35,36)}$. After a four-year clinical follow-up at least, the authors report the following mortality rates associated with HEE: 13\% in soft tissues, $35 \%$ in liver and $65 \%$ in lung ${ }^{(15,35)}$.

These angiocentric tumors are typically found in asymptomatic solitary masses, with poor-defined and infiltrative borders, which are located in superficial or deep soft tissue ${ }^{(4,12,37)}$. They are less frequent in the liver, lung, pleura, bones, skin, lymph nodes, central nervous system and meninges. Furthermore, they may present specific clinical aspects, namely more indolent clinical behavior in skin lesions $^{(4,5,8,12,19,21,24,26)}$.

It is possible to observe a centrifugal proliferation pattern of neoplastic cells originating from vessels, mainly veins, in approximately $50 \%$ of HEE. They are epithelioid endothelial cells that are assembled as short strings or nests, scattered in one

First submission on 14/11/12; last submission on 17/01/13; accepted for publication on $05 / 02 / 13$; published on 20/04/13

1. Post-graduate in Pathology and Cytopathology by Instituto Nacional de Câncer (INCA).

2. Post-graduate in Anatomy Pathology by INCA.

3. Post-graduate in Anatomy Pathology by Universidade Federal Fluminense (UFF); doctor in Sciences by Escola Nacional de Saúde Pública/Fundação Oswaldo Cruz (FIOCRUZ). 
non-inflammatory fibromyxoid or sometimes hyaline stroma. The neoplasia occupies the tissue surrounding the vessels, which tend to be preserved, and it also fills in the lumen in the form of "tufts" $(4,12,32,37)$. Epithelioid cells are polygonal or round with wide eosinophilic cytoplasm, although foci of fusiform cells may be occasionally found ${ }^{(12,26,31)}$. It has round or ovoid vesicular nuclei, fine and dispersed chromatin, with no evident nucleoli. Prominent intracytoplasmic vacuoles of tumor cells may be confused with true vascular spaces, mainly when they occasionally contain erythrocytes ${ }^{(1 .}$ $2,4,28,32)$. They are morphological aspects that normally overlap with other neoplasias such carcinomas, melanomas and other epithelioid sarcomas, hindering HEE diagnosis ${ }^{(27)}$.

In general, cellular atypia is discreet and the mitotic activity is low, although there may be significant atypia and high mitotic rate ( $>1$ mitosis/10 high power fields [HPF]). In association with the presence of necrosis and higher number of fusiform neoplastic cells, it may suggest a more aggressive clinical course, including distant metastasis ${ }^{(12,26,37)}$.

The vascular phenotype of this neoplasia is demonstrated by the immunohistochemical exam, including endothelial markers such as CD31, CD34 and Von Willebrand factor. The latter provides high specificity with cytoplasmatic marking, whereas CD31 and CD34 are more sensitive ${ }^{(3,22,25,28,32,33)}$.

Approximately $25 \%$ of HEE show immunoreactivity to cytokeratins and $45 \%$ to smooth muscle actin. The negativity to epithelial membrane antigen (EMA) is connected with non-epithelial lesions. More recently, some studies have proposed the use of podoplanin as a immunohistochemical marker to differentiate HEE from nonvascular tumors. Podoplanin is a transmembrane mucoprotein selectively expressed by lymphatic endothelial cells and also by some

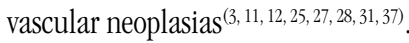

\section{OBJECTIVE}

The present study reports a series of thirteen cases of HHE in different topographies, diagnosed at the Pathology Division (Divisão de Patologia [DIPAT]) of Instituto Nacional de Câncer (INCA) from June 1996 until June 2011.

\section{MATERIAL AND METHODS}

This investigation describes thirteen cases of HEE, which were selected from DIPAT/INCA data archives from June 1996 until June 2011. Furthermore, a literature review was developed based on data from Pubmed in which the following descriptive terms were used: borderline vascular tumors, vascular tumors of intermediate malignancy and epithelioid hemangioendothelioma. Initially, a total of 18 patients with HEE were identified. The slides with histological sections, including hematoxylin and eosin stained samples (diagnostic routine) as well as immunohistochemical samples, were reviewed by two researchers (Albuquerque, AKAC and Romano,
S0). Five cases were excluded. Three of them did not have slides or blocks stored at DIPAT archive (diagnosed between 1997 and 1998). The other two cases presented soft tissue lesion in the upper limbs and there was no diagnostic concordance between the researchers, establishing as differential diagnoses epithelioid angiosarcoma and atypical fibro-histiocytic lesion.

13 cases of HEE included in this series correspond to six patients initially assisted at INCA, whose data were removed from clinical records and histopathological reports and seven patients were referred to other health services, all of them in Rio de Janeiro, for diagnosis and/or complementary immunohistochemical investigation. This investigation was approved by INCA research and ethics committee (protocol nº 121/2011).

\section{RESULTS}

13 patients were selected, six of which (46\%) were female and 7 (54\%) were male. The age ranged from 7 to 66 years, and the average age was 42. Only one case was diagnosed in a 7-year odd child and in two other cases there was no information on age. The most common clinical history was the presence of tumor growth or solid mass.

The proliferation of epithelioid endothelial cells with intracytoplasmic luminal formation in mixo-hyalin stroma (Figures 1 to 3) was observed in all cases, nevertheless it was not the predominant pattern in some of them. The vascular origin of these tumor cells was confirmed by immunohistochemical analysis with the following endothelial markers: CD31, CD34 and/or Factor VIII (Figure 4; Table). Additionally, there was some variation in the immunoreactive profile within the reviewed cases. In one of the cases of bone HEE (spinal cord), there was no immunopositivity for neither CD31 nor CD34. Moreover, Factor VIII was not assessed. In another case (pulmonary HEE), the three endothelial markers were not assessed. However, the morphological characteristics of these two cases were sufficient to establish HEE diagnosis.

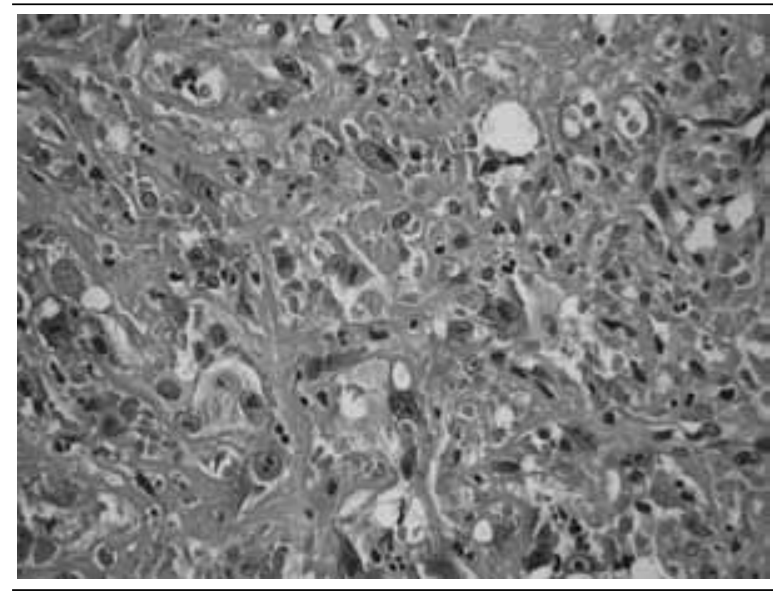

FIGURE 1 - HEE (HE, 40×)

Proliferation of epithelioid cells with nest or string formations in fibro-myxoid stroma.

HEE: epithelioid hemangioendothelioma; HE: bematoxylin and eosin. 


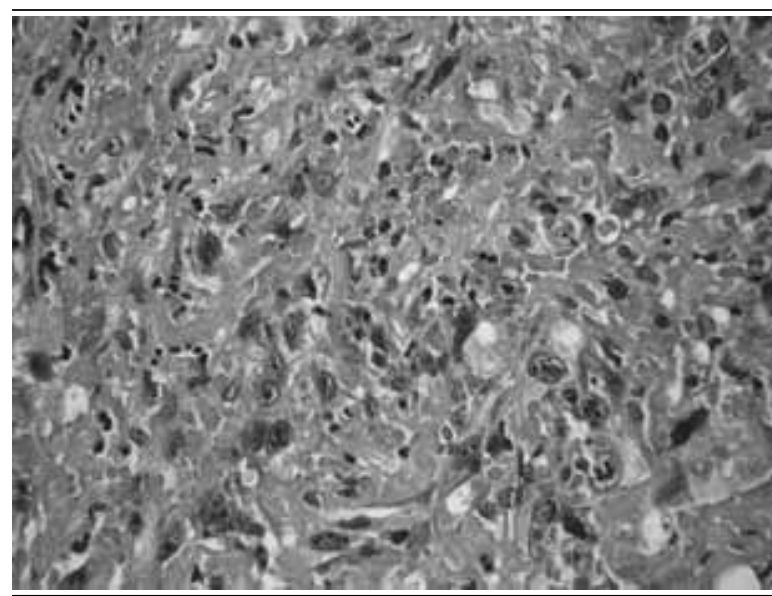

FIGURE 2 - HEE (HE, 40×)

Large neoplastic cells with wide cytoplasm and hyperchromatic nucleus. HEE: epithelioid hemangioendothelioma; HE: hematoxylin and eosin.

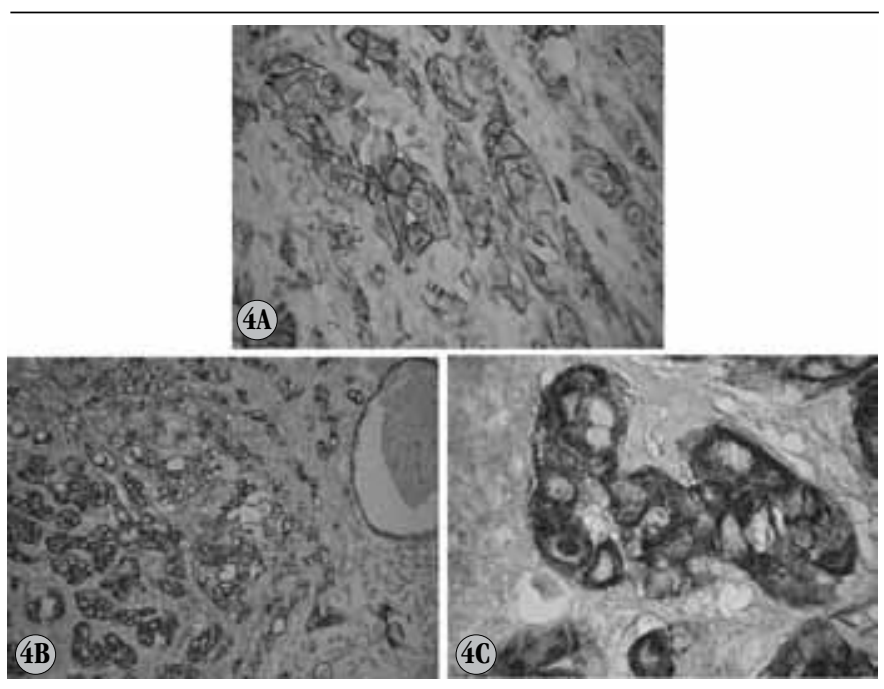

FIGURE 4 - HEE

4A) epithelioid cells displayed in nests, exhibiting membrane immunoexpression to CD31, endothelial marker (40x); 4B) diffuse neoplastic expression for CD34 antibody, endothelial marker (10×); 4C) neoplastic cells exbibiting immunoreactivity to Factor VIII, with clear cytoplasmic expression (100x)

HEE: epithelioid hemangioendothelioma.

Superficial and deep soft tissues represented the most affected topography (three cases; 23\%), followed by head-neck (two cases; $15 \%$ ), mediastinum (two cases; $15 \%$ ), bone (two cases; $15 \%$ ) and lung (two cases; $15 \%$ ). Liver (one case; $8 \%$ ) and lymph node (one case; $8 \%$ ) were the other affected topographies (Table).

The three patients with HEE in soft tissue were male and their ages varied from 29 to 53 years. Two of them occurred in the lower limbs and in only one case there was a four-year clinical follow-up with the patient remaining alive without disease (Table). HEE in head and neck occurred in two female patients ( 7 and 37 years of age), one affecting the parotid region and the other involving the gingival ridge with subjacent bone involvement. The latter showed

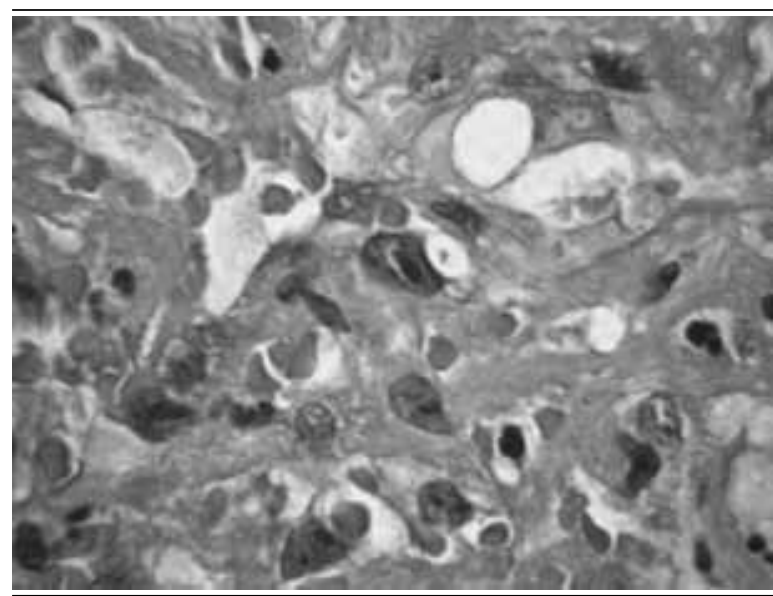

FIGURE 3 - HEE (HE, 100×)

Epithelioid neoplastic cells with cytoplasmic lumens, sometimes containing erythrocytes.

HEE: epithelioid hemangioendothelioma; HE: hematoxylin and eosin.

local relapse two years after diagnosis (Table). The two cases of mediastinum lesions showed indolent behavior, both with diseasefree survival rates of approximately five to six years. As to the two cases of bone HEE (Figure 5), the diagnosis was established with biopsy performed in other institutions and the material was sent to the medical appointment at DIPAT. One of these patients had a one-year follow-up, presenting no disease (Table).

Among the pulmonary HEE (Figure 6), one of them showed aggressive behavior, in which the patient progressed to death two years after diagnosis. The second case was diagnosed through material sent to the medical appointment and the clinical information revealed a pulmonary nodule with low contrast uptake. There was no clinical follow-up in this case (Table).

Liver HEE was diagnosed through investigation into report of multiple coalescent nodules in the liver. Surgical resection of the left hepatic lobule and segment $V$ was conducted. There was local relapse and disease spread to other organs and adjacent structures such as

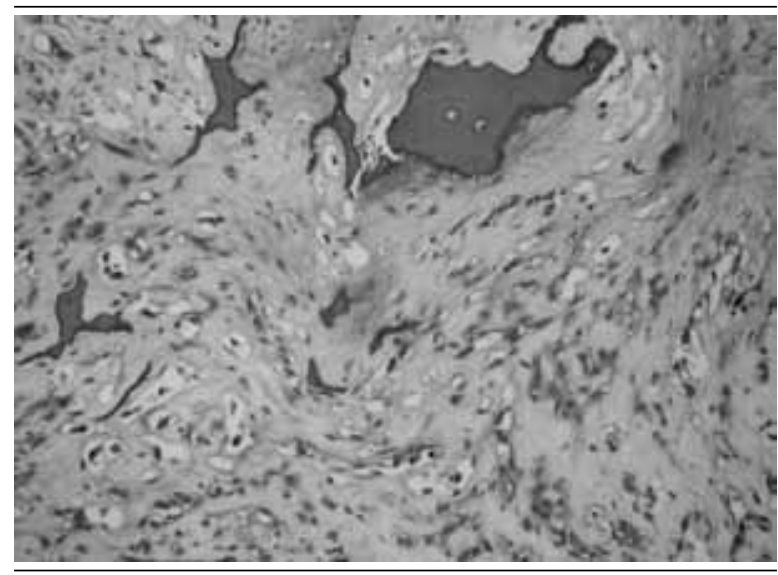

FIGURE 5 - HEE affecting the bone tissue (HE, 20×)

Strings of epithelioid endothelial cells scattered in fibro-myxoid stroma. HEE: epithelioid hemangioendothelioma; HE: hematoxylin and eosin. 
TABLE - Cases of HEE diagnosed in 15 years at DIPAT-INCA

\begin{tabular}{|c|c|c|c|c|c|c|c|c|c|}
\hline \multirow{2}{*}{ Age } & \multirow{2}{*}{ Gender } & \multirow{2}{*}{$\begin{array}{c}\text { Signs/ } \\
\text { symptoms }\end{array}$} & \multirow{2}{*}{ Topography } & \multirow{2}{*}{ Relapse } & \multirow{2}{*}{ Metastases } & \multicolumn{3}{|c|}{ Immunohistochemistry } & \multirow{2}{*}{$\begin{array}{c}\text { Clinical } \\
\text { Follow-up }\end{array}$} \\
\hline & & & & & & CD31 & CD34 & Factor VIII & \\
\hline 53 & M & Axillary mass & Soft tissue & $\mathrm{N}$ & $\mathrm{N}$ & $\mathrm{NA}$ & $\mathrm{NA}$ & + & NF \\
\hline $\mathrm{NI}$ & M & Verrucous tumor in the thigh & Soft tissue & $\mathrm{N}$ & $\mathrm{N}$ & $\mathrm{NA}$ & + & $\mathrm{NA}$ & NF \\
\hline 29 & M & Nodule in the plantar area & Soft tissue & $\mathrm{N}$ & $\mathrm{N}$ & $\mathrm{NA}$ & + & $\mathrm{NA}$ & AWD; 4 years \\
\hline 7 & $\mathrm{~F}$ & Lesion in the gingival ridge & Head and neck & Y & $\mathrm{N}$ & + & + & + & AWD; 2 years \\
\hline 55 & F & Mediastinum tumor & Mediastinum & $\mathrm{N}$ & $\mathrm{N}$ & + & + & + & ADF; 5 years \\
\hline 63 & $\mathrm{~F}$ & NI & Mediastinum & $\mathrm{N}$ & $\mathrm{N}$ & + & + & $\mathrm{NA}$ & ADF; 6 years \\
\hline 66 & F & Dorsal spine lesion & Bone & $\mathrm{N}$ & $\mathrm{N}$ & - & - & $\mathrm{NA}$ & ADF; 1 year \\
\hline NI & M & Pulmonary nodule with low contrast uptake & Lung & $\mathrm{N}$ & $\mathrm{N}$ & + & + & + & $\mathrm{NF}$ \\
\hline 48 & $\mathrm{~F}$ & Tumors in lobe $\mathrm{E}$ and segment $\mathrm{V}$ of the liver & Liver & Y & $\mathrm{N}$ & - & + & + & DWD; 5 years \\
\hline 39 & M & $\begin{array}{c}\text { Pulmonary nodule and SC lymphadeno- } \\
\text { megaly }\end{array}$ & $\begin{array}{l}\text { SC lymph } \\
\text { node }\end{array}$ & $\mathrm{N}$ & Y & + & $\mathrm{NA}$ & + & DWD; 1 month \\
\hline
\end{tabular}

HEE: epithelioid hemangioendothelioma; DIPAT: Pathology Division; INCA: Instituto Nacional de Câncer; M: male; F: female; NI: not informed; SC: supraclavicular; N: no; S: yes; NA: not assessed; +: positive; -: negative; NF: no follow-up; ADF: alive and disease-free; AWD: alive with disease; DWD: dead with disease.

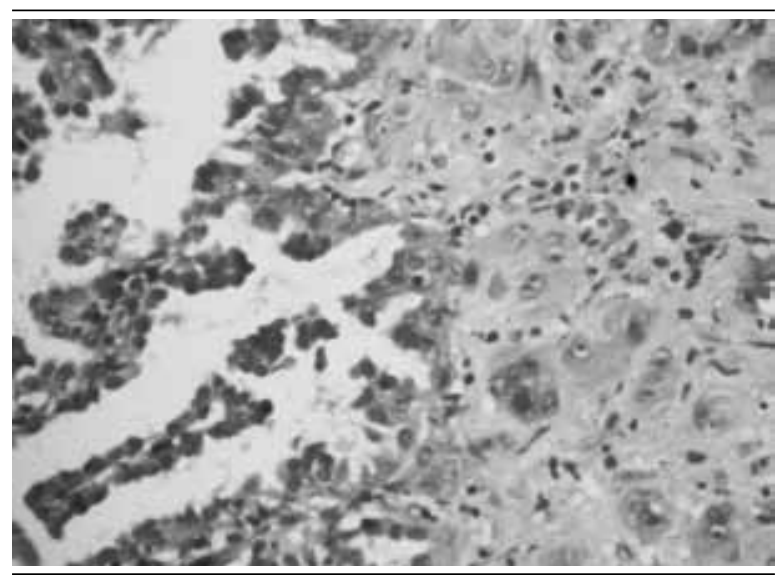

FIGURE 6 - Pulmonary HEE (HE, 20x)

Proliferation of epithelioid neoplastic cells in the pulmonary parenchyma. It is possible to observe alveolar spaces with reactive pneumocytes.

HEE: epithelioid hemangioendothelioma; HE: hematoxylin and eosin.

diaphragm and peritoneum, progressing to death approximately five years after first diagnosis (Table).

In this series, one of the cases was particularly worth noting, in which HEE diagnosis was established through supraclavicular lymph node exam (Figure 7), reporting the concomitant presence of a pulmonary nodule. In this particular case, the disease progressed aggressively, leading to patient's death one month after diagnosis (Table).

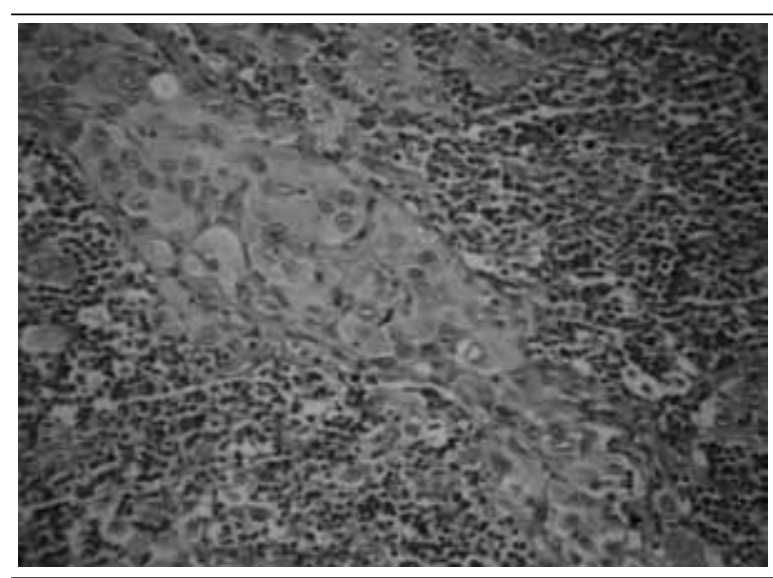

FIGURE 7 - HEE affecting lymph node (HE, 20×)

Polygonal neoplastic cells with wide eosinophilic cytoplasms, exbibiting intracytoplasmic vacuoles amid lymphoid tissue.

HEE: epithelioid hemangioendothelioma; HE: hematoxylin and eosin.

\section{DISCUSSION}

HEE may be diagnosed at any age, but it is rare in children ${ }^{(28,35)}$. It arises more frequently as a solitary tumor, generally painless, in superficial or deep soft tissues and/or in skin, mainly in the lower limbs ${ }^{(28)}$.

HEE is a neoplasia with uncertain biological behavior, in which some patients present local aggressive behavior, with possible distant 
metastasis, whereas others have indolent clinical course and/or progression to cure after complete lesion resection. In patients with visceral involvement, the clinical behavior is notably aggressive, as it was corroborated by the present investigation.

The pathogenicity of this neoplasia has not been totally elucidated. For some authors, the distinction among hemangiendotheliomas is controversial, inasmuch as they believe these lesions represent a subtype of low grade angiosarcoma, which is less cellular, less pleomorphic and it has lower mitotic activity ${ }^{(18)}$.

According to the World Health Organization (WHO) (2002) classification, the tumors with intermediate malignant potential fit into two groups: 1) those with local aggressiveness; 2) those rarely metastatic. According to this classification, HEE fits in the second group, with a metastasis rate varying from $15 \%$ to $32 \%{ }^{(7)}$. Nonetheless, the local aggressiveness of this tumor may be taken into consideration in its therapeutic approach, insofar as surgical resections with affected borders are commonly linked with high rates of local recurrence, mostly in well-defined and infiltrative lesions, mainly in head and neck ${ }^{(27,29)}$.

Analyzing a series of 49 cases of HEE in soft tissues, Deyrup et al. concluded that large tumors $(>3 \mathrm{~cm}$ diameter) with high mitotic activity (more that 3 mitosis/50 HPF) are associated with a more aggressive clinical course. The cytological atypia, the presence of fusiform neoplastic cells and necrosis are not associated with tumor prognosis $^{(7)}$.

In the present series of three cases of HEE in soft tissues, there was a four-year clinical follow-up in just one case, and patient presented no disease. The lesions found in the head and neck are usually originated from soft tissues. X-ray exams reveal that approximately 26\% of the cases exhibit reabsorption and/or adjacent bone destruction. In the oral cavity, the most affected locations are tongue and gingival ridges. In the head and neck, there are also cases reporting the nasal cavity, parotid gland, larynx and thyroid.

The literature highlights that lesions in the upper gingiva and oral mucosa are the ones that most relapse $e^{(8,10,13,32)}$. According to this data, it is particularly worth mentioning one case in this series, a 7 year-old patient who presented HEE relapse in the upper gingival ridge with adjacent bone destruction two years after the first surgical resection. The other case of HEE in the head and neck, diagnosed in the parotid, had a two-year follow-up, which was a disease-free period.

In the mediastinum, HEE seems to be originated from medium sized and large veins such as superior vena cava, brachiocephalic vein and innominate vein. In the cases reported in the literature, mediastinal HEE shows more indolent clinical course in comparison with hepatic and pulmonary topography ${ }^{(0,23)}$. Herein, two cases of mediastinal HEE are reported. Both progressed favourably, with a disease-free survival rate of five to six years. Opposed to what is observed in soft tissues, HEE in bones tend to be multifocal and/or multicentric, remaining uncertain whether these lesions are synchronic or metastatic $^{(7,16,20,34)}$. As well as other vascular tumors observed in the bone tissue, HEE is infrequent, with higher incidence among young adults, with no gender predominance. They are lytic lesions, with well-defined borders or not, which may arise in any other part of the bone system, mainly in the lower limbs. In terms of histology and clinical behavior, this bone vascular tumor is similar to the ones found in other organs, hence there is poor association between its morphological aspects and natural history. Nevertheless, Kleer et al. noted that the visceral involvement is a major predictive criterion of poor prognosis in bone $\mathrm{HEE}^{(17)}$. Considering its multifocality, it is recommended that the patient should be screened as to other possible lesions at diagnosis ${ }^{(14,16,17,20,34,37)}$. One patient from the two cases of bone HEE lived without disease for a year, period in which he was clinically followed. There was no further information on clinical follow-up as to the second patient.

Pulmonary HEE, previously described as intravascular bronchioloalveolar, is a rare neoplasia, commonly multifocal, which affects young women. Moreover, it exhibits indolent clinical course. Its multifocality is a significant criterion on the discussion whether this pulmonary tumor is primary or metastatic from lesions located in other organs ${ }^{(3,30)}$. Clinically and radiologically speaking, they constitute bilateral nodules of varied diameter, generally smaller that $2 \mathrm{~cm}$, which may be linked or not with pleural effusion and/or respiratory symptoms ${ }^{(2)}$. The histomorphological aspects, as it occurs in other organs, are corroborated by the immunohistochemical profile, which in this organ includes positivity for friend leukemia integration-1(FLI-1) and negativity for thyroid transcription factor-1 (TTF-1) and cytokeratin (CK) 5/6.

Amin et al. analyzed the survival prognostic factors in patients with pulmonary HEE and concluded that, despite the arbitrariness in trying to establish the prognosis, the presence of pulmonary symptoms, mainly pleural effusion and hemoptysis, weight loss, anemia and extrapulmonary disease (namely affected lymph nodes and distant metastases) is associated with a lower survival rate ${ }^{(2,30)}$. Herein, both cases of pulmonary HEE were with male patients: the first progressed to death two months after diagnosis and the second presented no clinical follow-up. Another case with clinical history of pulmonary nodule and HEE diagnosis after supraclavicular lymph node exam showed aggressive behavior and rapid progression to death.

Pleural HEE is extremely rare. It is clinically characterized by small nodules, commonly scattered in pleura and/or juxtapleural pulmonary parenchyma, which requires differential diagnosis with mesothelioma and carcinomatosis. Opposed to pulmonary tumors, pleural HEE affects more frequently elderly men and its clinical course is considerably more aggressive, with spread to pulmonary parenchyma and bone metastases at diagnosis ${ }^{(19)}$. In this series, there were no such cases.

The etiology and risk factors of primary hepatic HEE, first described in 1984, have not been fully clarified yet.

Mehrabi et al., based on a wide review of series published in the international literature reporting the diagnosis of HEE in the liver, concluded that this tumor is more frequently found in middle-aged women. They may be characterized by a unique nodule or multiple and diffuse lesions, the latter are evidence of an advanced stage of the disease, 
including extra-hepatic involvement ${ }^{(24)}$. The clinical symptomatology is also extensive and the most frequent complaint is abdominal pain in the right hypochondrium, followed by hepatomegaly and weight loss. The definite diagnosis is achieved by the histopathological analysis of the lesion. In the hepatic topography, the following peculiarities are worth noting: a) despite the infiltrating standard of the lesions, hepatic acini and portal spaces tend to be preserved; b) vascular invasion is characteristic, forming "tumoral tufts" in portal vein branches and in terminal portal venules; c) presence of epithelioid or dendritic tumor cells with intracytoplasmic lumen, with vascular origin, characterized by immunoreactivity to CD31, CD34 and/or Factor VIII antigens; d) lack of immunoreactivity to epithelial markers, mainly cytokeratins. In the presence of one or more aspects, HEE diagnosis should be considered ${ }^{(27)}$. In the only case of hepatic HEE of this series, the diagnosis was achieved through the morphological characteristics allied with immunonegativity to cytokeratins and Hep-par antibody, which is highly sensitive to hepatic cells.

In several cases, the differential diagnosis between HEE and primary and/or metastatic carcinomas exclusively based on the analysis of HE stained sections may be challenging, thus the use of immunohistochemical markers are of paramount importance. The uncertain malignity of this vascular tumor is also observed in hepatic lesions, in which prognosis is widely variable, from solitary slowly growing nodules to diffuse rapidly progressive lesions, including peritoneal sarcomatosis. Although surgical resection is the best recommended approach, the rarity of this disease hinders the establishment of standardized therapeutic protocols, therefore the approach and follow-up should be established individually ${ }^{(21,24)}$. The hepatic HEE case of this series showed aggressive behavior. There was relapse with spread to adjacent organs and the patient progressed to death five months after diagnosis.
With the objective of improving diagnostic accuracy of these tumors, studies have been conducted in order to establish other auxiliary tools. Recently, other immunohistochemical antibodies have been proposed and added to the traditional panel of endothelial markers. Podoplanin, a specific transmembrane protein of the lymphatic endothelium, the overexpression of glucose transporter (GLUT1) as a potential marker for malignant transformation, peptidyl-prolyl cis-trans isomerase (FKBP12) and cytosolic protein receptor of immunosuppressing agents are among them. Notwithstanding, these are limited data that require further studies in order to substantiate these recent findings ${ }^{(11,18,27)}$.

\section{CONCLUSIONS}

HEE affects men and women equally at any age and it is rare in children. It is frequently a solitary painful tumor in superficial or deep soft tissues. When it occurs in the viscera, namely liver and lung, the clinical course is more aggressive.

HEE diagnosis should be considered every time there is an epithelioid cell lesion with minimum pleomorphism, intracytoplasmic vacuoles, low mitotic activity and little or no necrosis. The vascular nature of the cells should be corroborated by immunohistochemical analyses, even considering the fact that the expression of conventional endothelial markers (CD31, CD34 and Factor VIII) is heterogeneous in most cases.

Herein, it was reported a series of thirteen cases of HEE, in which several patterns of clinical presentation and biological behavior are illustrated. The lack of uniformity of these clinical characteristics, allied with the specificity of this tumor, corroborates its fewer reports in international literature.

\section{RESUMO}

Introdução: O hemangioendotelioma é um tumor vascular de malignidade intermediária, localmente agressivo e com risco de metástase. A variante epitelioide, a mais agressiva, acomete igualmente homens e mulheres em qualquer idade é rara na infância. Apresenta-se como tumoração solitária, geralmente dolorosa, em partes moles, superficiais ou profundas; menos frequentemente, acometefígado, pulmão, ossos, pele, linfonodos e sistema nervoso central. Microscopicamente, mostram células epitelioides com vacúolos intracitoplasmáticos, baixa atividade mitótica, pouca ou nenhuma necrose, tendo sua natureza vascular comprovada por estudos imuno-histoquímicos (CD31, CD34, Fator VIII). Objetivos e material e métodos: Por meio de busca nos arquivos da Divisão de Patologia (DIPAT) do Instituto Nacional de Câncer (INCA), de 1996 a 2011, foram encontrados e revisados 13 casos de hemangioendotelioma epitelioide (HEE). Resultados e discussão: Sete casos ocorreram em homens e seis, em mulheres, com idade média de 42 anos, variando de 7 a 66 anos de idade. As localizações mais frequentes foram partes moles (três pacientes; 23\%); cabeça-pescoço, mediastino, osso e pulmão, (dois pacientes cada; 15\%); fígado e linfonodo (um paciente cada; 8\%). Houve seguimento clínico de nove pacientes: cinco estavam vivos e livres de doença (de um a seis anos após o diagnóstico); dos quatro pacientes que apresentaram HEE agressiva, três evoluíram a óbito com doença (de um mês a cinco anos) e um recidivou dois anos após o diagnóstico e está vivo com a doença. Conclusão: Esta série de 13 casos de HEE, cujos diagnósticos foram firmados em bases morfológicas e/ou imuno-histoquímicas, demonstra os diferentes padrões de apresentação clínica e o comportamento biológico da doença.

Unitermos: tumores vasculares incertos; tumores vasculares de malignidade intermediária; hemangioendotelioma epitelioide. 


\section{REFERENCES}

1. ABATI, A.; CAJIGAS, A.; HIJAZI, Y. W. Metastatic epithelioid hemangioendothelioma in a pleural effusion: diagnosis by cytology. Diagn Cytopathol, v. 11, p. 64-7, 1994.

2. AMIN, R. M. S. et al. Risk factors and independent predictors of survival in patients with pulmonary epithelioid haemangioendothelioma. Review of the literature and a case report. Respirology, v. 11, p. 818-25, 2006.

3. BIALAS, M.; PAPLA, B.; BULANDA, A. Immunohistochemical investigation of selected endothelial markers in pulmonary epithelioid haemangioendothelioma. Pol J Pathol, v. 4, p. 236-40, 2011.

4. CALONJE, E; FLETCHER, C. D. M. Vascular tumors. In: Fletcher, C. D. M. Diagnostic bistopathology of tumors. 3. ed. Philadelphia, USA: Churchill Livingstone Elsevier, 2007, p. 41-81.

5. CHATELAIN, B. et al. Lémangioendotheliome epithé lioi"de du maxillaire: a propos d'un cas et revue de la litterature. Rev Stomatol Chir Maxillofac, v. 110, p. 45-9, 2009.

6. CHI, A. C. et al. Epithelioid hemangioendothelioma of the oral cavity: report of two cases and review of the literature. Oral Surg Oral Med Oral Pathol Oral Radiol Endod, v. 100, n. 6, p. 717-24, 2005.

7. DEYRUP, A. T. et al. Epithelioid hemangioendothelioma of soft tissue: a proposal for risk stratification based on 49 cases. Am J Surg Pathol, v. 32, n. 6, p. 924-7, 2008.

8. ELLIS, G. L. et al. Epithelioid hemangioendothelioma of the head and neck: a clinicopathologic report of twelve cases. Oral Surg Oral Med Oral Pathol, v. 61, p. 61-8, 1986.

9. FERRETTI, G. R. et al. Epithelioid hemangioendothelioma of the superior vena cava: computed tomography demonstration and review of the literature. J Thorac Imaging, v. 13, p. 45-8, 1998.

10. FLAITZ, C. M. et al. Primary intraoral epithelioid hemangioendothelioma presenting in childhood: review of the literature and case report. Ultrastruct Pathol, v. 19, p. 275-9, 1995.

11. FUJII, T. et al. Podoplanin is a useful diagnostic marker for epithelioid hemangioendothelioma of the liver.Modern Pathology, v. 21, p. 125-30, 2008.

12. GOH, S. G. N.; CALONJE, E. Cutaneous vascular tumours: an update. Histopathology, v. 52, p. 661-73, 2008.

13.GORDÓN-NÚÑEZ, M.A.et al. Intraoral epithelioid hemangioendothelioma: a case report and review of the literature. Med Oral Patol Oral Cir Bucal, v. 15, n. 2, p. 340-6, 2010.

14. IGNACIO, E. A. et al. Epithelioid hemangioendothelioma of the lower extremity. RadioGraphics, v. 19, p. 531-7, 1999.

15. JANG, K. Y. et al. Pulmonary epithelioid hemangioendothelioma: a tumor presented as a single cavitary mass.J Korean Med SCI, v. 18, p. 599-602, 2003.

16. KABUKCUOGLU, F. et al. Epithelioid hemangioendothelioma of bone. Acta Orthop Traumatol Turc, v. 40, n. 4, p. 324-8, 2006.

17. KLEER, C. G.; KRISHNAN, U. K.; MCLEOD, R. A. Epithelioid hemangioendothelioma of bone. Am J Surg Pathol, v. 20, p. 1301-11, 1996.

18. KÖSEMEHMETOGLU, K.; GEDIKOGLU, G.; RUACAN, S. Morphological and immunohistochemical features of malignant vascular tumors with special emphasis on GLUT1, and FKBP12 expressions. Turk J Patologi Derg, v. 27, p. 57-67, 2011.
19. LEE, Y. J. et al. Pleural epithelioid hemangioendothelioma. Yonsei Med J, v. 49, n. 6, p. 1036-40, 2008.

20. LIU, Q. et al. Multicentric epithelioid hemangioendothelioma involving the same lower extremity: a case report and review of literature. International JMed Sci, v. 8, n. 7, p. 558-63, 2011.

21. LUPINACCI, R. M.; ROCHA, M. S.; HERMAN, P. Hepatic epithelioid hemangioendothelioma: an unusual lesion of the liver. Clin Gastroenterolo Hepatol, v. 10, p. 15-6, 2012.

22. MAKHLOUF, H. R. et al. Epithelioid hemangioendothelioma of the liver. A clinicopathologic study of 137 cases. Cancer, v. 85, p. 562-82, 1999.

23. MANSOUR, Z; NEUVILLE, A.; MASSARD, G. Mediastinal epithelioid haemangioendothelioma: a rare mediastinal tumor. Interact Cardiovas Thorac Surg, v. 10, p. 122-4, 2010.

24. MEHRABI, A. et al. Primary malignant hepatic epithelioid hemangioendothelioma: a comprehensive review of the literature with emphasis on the surgical therapy. Cancer, v. 107, n. 9, p. 2108-21, 2006.

25. MENTZEL, T. et al. Epithelioid hemangioendothelioma of skin and soft tissues: clinicopathologic and immunohistochemical study of 30 cases. Am J Surg Pathol, v. 21, p. 363-74, 1997.

26. MOHTASHAM, N. et al. Epithelioid hemangioendothelioma of the oral cavity: a case report. J Oral Sci, v. 50, n. 2, p. 219-23, 2008.

27. NAQVI, J. et al. Epithelioid hemangioendothelioma of the head and neck: role of podoplanin in the differential diagnosis. Head Neck Pathol, v. 2, p. 25-30, 2008 .

28. O'HARA, C. D.; NASCIMENTO, A. G. Endothelial lesions of soft tissues: a review of reactive and neoplastic entities with emphasis on low-grade malignant ("borderline") vascular tumors. Adv Anat Pathol, v. 10, n. 2, p. 69-87, 2003.

29. PATNAYAK, R. et al. Epithelioid hemangioendothelioma of nasal cavity. J Lab Physicians, v. 2, p. 111-3, 2010.

30. ROSENGARTEN, D. et al. Pulmonary epithelioid hemangioendothelioma. IMAJ, v. 13, p. 676-9, 2011.

31. SUN, Z. J. et al. Epithelioid hemangioendothelioma of the oral cavity. Oral Diseases, v. 13, p. 244-50, 2007.

32. TONG, G. X. et al. Fine needle aspiration biopsy of epithelioid hemangioendothelioma of the oral cavity: report of one case and review of literature. Diagn Cytopathol, v. 24, n. 3, p. 218-23, 2006.

33. TSUNEYOSHI, M. et al. Epithelioid hemangioendothelioma of bone, a clinicopathologic, ultrastructural and immunohistochemical study. Am J Surg Pathol, v. 10, p. 754-64, 1996.

34. VERBEKE, S. L. J.; BOVÉE, J. V. M. G. Primary vascular tumors of bone: a spectrum of entities? Int J Clin Exp Pathol, v. 4, n. 6, p. 541-51, 2011.

35. WEISS, S. W. et al. Epithelioid hemangioendothelioma and related lesions. Semin Diagn Pathol, v. 3, p. 259-87, 1986.

.; ENZINGER, F. M. Epithelioid hemangioendothelioma: a vascular tumor often mistaken for a carcinoma. Cancer, v. 50, p. 970-81, 1982.

.; GOLDBLUM J. R. Hemangioendothelioma: vascular tumors of intermediate malignancy. In: STRAUSS, M. Enziger and weis's soft tissue tumors. 5. ed. Philadelphia, USA: Mosby Elsevier, 2008, p.681-702.

\section{MAILING ADDRESS}

Ana Karla A. C. de Albuquerque

Rua Cordeiro da Graça, 156; Santo Cristo; CEP: 20220-400; Rio de Janeiro-RJ, Brazil; e-mail: akaca@ hotmail.com. 